\title{
Empirical Analysis of the Reality of Gender Inclusiveness of Participatory Forest Management Approach: The Case of Chilimo-Gaji Forest, West Shewa Zone, Oromia Region, Ethiopia
}

\author{
Tesfaye Samuel Saguye \\ Department of Disaster Risk Management and Sustainable Development, Institute of Cooperatives and Development Studies, Ambo \\ University, Ambo, Ethiopia
}

\section{Email address: \\ gezegofa@gmail.com}

\section{To cite this article:}

Tesfaye Samuel Saguye. Empirical Analysis of the Reality of Gender Inclusiveness of Participatory Forest Management Approach: The Case of Chilimo-Gaji Forest, West Shewa Zone, Oromia Region, Ethiopia. International Journal of Science, Technology and Society. Vol. 5, No. 4, 2017 , pp. 74-86.

doi: $10.11648 /$ j.ijsts.20170504.14

Received: August 8, 2016; Accepted: October 1, 2016; Published: June 21, 2017

\begin{abstract}
Governments from the commencement of nation-states have usurped forest management and use rights from local forest dependent societies as they perceive these societies as being opportunistic non-conservationists, thus dismissing their capability to manage their forests on a sustainable basis. As a result of this, the Conventional forest management system and practice have failed to improve the forest condition as well as to sustainably address the livelihood of the local community. In recognition of continued deforestation, degradation and loss of biodiversity associated with the mainstream "fences and fines" forest management system a new regime has practiced in a few national forest priority areas since 1990s, emphasizing the need to incorporate the aspiration of local people in forest conservation strategies in Ethiopia. This study was conducted in ChilimoGaji forest which is one of the oldest PFM intervention sites in Ethiopia. The main purpose of this study was to analyze the reality of gender inclusiveness of the newly introduced forest management system. Both qualitative and quantitative methods of data collection particularly, semi-structured questionnaire survey, focus group discussions and key informant interviews were employed. Analysis of the data reveals that participatory forest management process in the study area was women's exclusionary in reality even from the lowest nominal typology of participation to the highest in hierarchy of participation, interactive and empowerment in entire participatory forest management process. The study also identified the exclusionary factors which are constraining gender participation such as exclusionary membership rules, gender division of labour, poor educational back grounds, and poor enactment of already established rules and so on. So, the study suggests serious empowerment and awareness creation interventions should be taken and membership rules and women's inclusion in key decision-making positions should receive due attention.
\end{abstract}

Keywords: Gender, Participation, Participatory Forest Management, Chilimo-Gaji-Forest

\section{Introduction}

\subsection{Background}

Forests have enormous ecological, economical and sociocultural significances. Forests constitute critical habitat for humanity, providing a range of ecological and environmental services including protection of biodiversity, sequestration of carbon, provisioning of fresh air, renewal of soil fertility, and maintenance of hydrological flows (FAO, 2011; Shackleton et al., 2007). Rural poor communities worldwide also depend on forests heavily, as these contribute significantly to their livelihoods, providing basic needs, cash resources, and safety-nets during times of crisis (World Bank, 2000; USAID, 2006; Scherl et al., 2004). Regrettably, despite widespread acknowledgment of the significance of forests, it has been very difficult to tackle deforestation, which continues to represent a major global challenge. Globally, the forestry sector has over the years been faced by a myriads of challenges including; excision of state forest land, 
indiscriminative destruction of natural forests, poaching of rare species, weak governance structures, and lack of resources to regulate, lack of incentives to enhance communities participation and the duplication of laws and regulations (Barrett et al., 2001; Bedru, 2007).

Governments from the commencement of nation-states have usurped forest management and use rights from local forest dependent societies as they perceive these societies as being opportunistic non-conservationists, thus dismissing their capability to manage their forests on a sustainable basis (Saldanha, 2007). Centralized control imposes strict regulations that prohibit the use of forest produce, including wildlife (Agrawal and Ostrom, 2008). One of the negative immediate impacts of forest centralization is the loss of local control over forest resources and the reduced role of local institutions in managing forests. Forest dependent communities, devoid of any legal capacity to protect the resource encroach upon the protected forests to make up for the loss of use rights and incentives to manage their forests (Ostrom, 1990; Nemarundwe, 2003)

Forest resources in Ethiopia have been continuously depleting in terms of both area coverage and quality (Gete, 2010; Hurni, et al., 2010). Many areas of the country are already deforested and subject to increased erosion, landslides, siltation of rivers, pollution of surface waters and uncontrolled disposal of solid waste (Akililu, 2001). The Conventional forest management system and practice have failed to improve the forest condition as well as to sustainably address the livelihood of the local community (FARM Africa, 2005; Melaku, 2003). The state forest department with their protectionist orientation had been trying to police their territories from local people with an adamant zeal. In the process, there has been a phenomenal growth of conflict and lack of trust between the government and local communities. In recognition of the continued forest deforestation, degradation and loss of biodiversity associated with the conventional "fences and fines", a new discourse has arisen since the 1990s, emphasizing the need to incorporate the aspirations of local people in forest conservation strategies. The new forest management paradigm based on emerging theories of common pool resource management aimed to achieve dual-objective of sustainable forest utilization and equitable rural development (Hobley, 1991; Ostrom, 1998, Sunderlin et al., 2008). This new approach, often referred to as participatory forest management (PFM), allows local communities in the vicinity of protected areas or state-managed forests to participate in the conservation process and links conservation objectives with the local development needs of the people (Habtemariam et al., 2009; Garuma, 2000; Winberg, 2010).

Participatory forest management (PFM) was introduced in Ethiopia around the mid-1990s as a new system of forest governance (Melaku, 2003; Mulugeta and Melaku, 2008; Zelalem, 2005). PFM was hoped to avert the persistent problems of deforestation and to deliver better social and economic outcomes compared with the former centralized command-and-control resource management approach. In the
Ethiopian context, PFM is recognized as a co-governance institutional arrangement where forest management responsibilities and use rights are legally shared between a government agency and a community-based organization (CBO), such as forest user groups or forest cooperatives (Melaku, 2003). Under PFM, the parties come into mutually enforceable agreements that define their respective roles, responsibilities, benefits and authority in the management of forest resources. These agreements are ratified by all parties through a forest management agreement. In sharp contrast with the old 'command and control' system of forest governance, PFM recognizes local communities' stake in managing and improving the condition of the forests, rather than characterizing them as an inevitable destructive force. Chilimo-Gaji forest is one of the oldest PFM intervention sites in Ethiopia in which the government had invited local people to participate in planning, designing, implementing, managing and benefit sharing of forest resources under the participatory forest management program (Garuma, 2000).

The deterioration of forests has gender implications as women continue to bear the burden of walking longer distances for water, food and fuelwood FAO, 2012). It is primarily the women who work with these resources and depend on them for the well-being of their families (Agarwal, 2010). So it is vital that women are put at the centre of whatever decisions are being made about how to manage these resources. It is increasingly evident that women living close to forests should become co-managers and coprotectors of forests and co-benefit sharers along with the men counterparts and the government (Agarwal, 1994; Upadhyay, 2005). Development practitioners and policy makers yet confronted with the reality that inequitable distribution of benefits and excluding a large proportion of forest users and managers from meaningful participation in decision making may not yield intended outcomes under planned Reduce Emissions from Deforestation and Degradation (REDD) initiatives or may further impair efforts at poverty reduction and sustainable resource management (Behrman et al., 2001). Of the total population of Ethiopia, $82 \%$ live in rural areas with women accounting for $50 \%$ (FAO, 2011). Hence, if gender considerations are taken as a weak link in designing and implementing forest related interventions and investments, there remains the danger of not only pushing women further into poverty, insecurity, conflicts and despair, but also of forest policies and investment frameworks failing to deliver results on the ground. The issues of gender participation in forest management merits attention, as it impacts on both the welfare of women and their households and potentially on the condition of the forest resource itself.

\subsection{Statement of the Problem}

It is argued that almost $50 \%$ of the population is women and real development of the society particularly in the rural area cannot really be made without their active participation. If we ignore gender, there is no doubt that we will fail in our efforts to strengthen forests' contribution to poverty 
reduction, biodiversity conservation and sustainable development (FAO, 2011). After years of neglect and marginalization, gender issues have at last found a firm foothold in many forest, land use and environmental policies (Shackleton et al., 2011). While the increased attention to gender is certainly good news, there is a risk that some of the newly 'gender-aware' institutions are motivated more by a sense of obligation than a conviction that gender matters (Agarwal, 2010). If this is the case, they are not only missing the point but also missing real opportunities for enhancing the effectiveness of their forest-based programmes and policies. Understanding the different uses and interaction with the forest by women and men should be considered an essential element of designing, planning and implementing forest management interventions (FAO 2007; FAO, 2001; USAID, 2001). Although women's knowledge and needs often differ from those of men, many programmes in reality continue to ignore these points when it comes to forestry management reality on the ground (Shackleton et al., 2011). Excluding women from their fair share of benefits and a meaningful role in decision making may undermine intended outcomes of development efforts (Agarwal, 2001).

Research has a role in generating knowledge that is central to how interventions can be designed to respond to men and women's needs, capabilities and priorities. Most of the studies on participatory forest management in Ethiopia have tried to measure the physical targets of participatory forestry (Garuma, 2000; Melaku, 2003; Mulugeta and Melaku, 2008; Zelalem, 2005). Despite many gender studies on forestry, however, empirical study based on specific socio-culture, economic and institutional context are still very relevant and are lacks adequacy. Therefore, this study was conducted in view of bridging this gap. The general objective of the study is to examine the nature and level of gender participation in Chilimo-Gaji participatory forest management. The specific objectives of this study are (i) to analyze level of gender participation in PFM in the study area; (ii) to identify exclusionary constraints that hinder women's active participation in PFM in the study area. This study attempted to the following research question (i) Is PFM really inclusive and equitable to women or not? (ii) What are the constraining factors of women's participation in PFM? (iii) What can be done to overcome these hindrances?

\subsection{Theoretical Framework}

Participation is a complex issue and the interplay of various actors and factors are involved in ensuring its application properly. "Participation" in its simplest of meanings implies people taking part, sharing, or acting together. Arnstein (1969) differentiated participation into eight levels ranging from low participation, where manipulation is commonplace, to high participation, where control rests in the hands of citizens. He thus refers to participation as the power of degree to which the actors control decision-making. The participation of local communities can range from local people providing labour for a project, to the involvement of local people in major decisions about a project. The World Bank (1996) defines the concept of participation as a process through which stakeholder's influence and share control over development initiatives, decisions, and resources that affect them.

According to the definition of the United Nations (1975), people's participation entails three interrelated but distinct processes: (1) the involvement of the people in decisionmaking, (2) the eliciting of their contribution to development programs, and (3) their participation in sharing the benefits from the development process. Participation has been taken as an end as well as means as described by Oakley and Marsden (1984). It is understood as a process of empowerment. Using Uphoff's (1991) classification of participation, the focus of this study has been on the following stages of participation: (1) in decision-making, (2) implementation of the participatory forest management activities (3) participation in social and economic benefit sharing. At its narrowest, participation in a group is defined in terms of nominal membership). In terms of objectives, ate its narrowest participation is judged almost entirely by its potential efficiency effects, and at its broadest by its ability to enhance equity, efficiency, empowerment and environmental sustainability (Uphoff, 1991).

This study has adopted Bina Agarwal's typology of participation framework for the analysis of men's and women's different levels and extent of participation (Table 1). Agarwal categorized the range of participation from the narrowest scope to the broadest in terms of its interactive dynamic processes. These typologies are judged by their potential efficiency effects and their ability to enhance equity, empowerment and environmental sustainability (Agarwal, 2001). More specifically, the paper tries to identify levels of participation by men and women and women's roles in managing and governing forests and its resources.

Table 1. Typology of Participation.

\begin{tabular}{ll}
\hline Form/Level Of Participation & Characteristic Features \\
\hline Nominal participation & Membership in the group \\
Passive participation & Being informed of decisions ex post facto; or attending meetings listening in on \\
decision-making, without speaking up
\end{tabular}

(Source: Agarwal, 2001) 


\section{Methodology}

\subsection{Description of the Study Area}

The study was conducted in Chilimo-Gaji forest, which is one of the oldest PFM intervention sites in Ethiopia, located in Dendi district, which is one of the 18 districts found in West Shewa zone of Oromia regional state. Dendi district is bordered on the south by the Southwest Shewa Zone, on the west by Ambo, on the north by Jeldu, and on the east by Ejerie. The district's capital, Ghinchi is located 80 kilometers west of Addis Ababa on the Addis Ababa-Naqamte road. The district has a total area of 109,729 ha. It is located some 78 $\mathrm{km}$ southwest of Addis Ababa, between 38005' $\mathrm{E}$ to 38015'E and $9000 \mathrm{~N}$ to $10008^{\prime} \mathrm{N}$, with elevations ranging from 2000 to $3200 \mathrm{~m}$ a.s.l (Melaku, 2003). The population of the district is 209,554 . It has 48 rural kebeles and seven urban and semiurban kebeles; out of which five towns like Ginchi, Olankomi, Asgori and Bodda Asgori have municipal status. The highest point in the district is Mount Dendi $(3260 \mathrm{~m}$ a.s.l), located on the border with Wonchi district.

\subsection{An Overview of Chilimo-Gaji Forest and Establishment of PFM}

Chilimo-Gaji Forest represents the remnants of the dry Afro-montane forests in the central plateau of Ethiopia. The main species in the canopy layers are Junipers procera, Podocarpus falcatus, Prunus africana, Olea europaea subspecies cuspidata, Hagenia abyssinica, Apodytes dimidiata, Ficus spp., Erythrina brucei, and Croton macrosytachus (Melaku, 2003). Local communities use this forest as a grazing land for their cattle. This forest is also home to some 150 bird species, of which five are Ethiopian endemics and many more are Afro Tropical Highlands' biome species (EWNHS, 1996). Chilimo forest is characterized by the presence of Juniperus procera (Tsid), Podocarpus falcatus (Zigba), Prunus africana, (Tikur Enchet) Olea europaea subspecies cuspidata, (Weyra), Hagenia abyssinica, (Kosso) and Apodytes dimidiata, Ficus spp. (Shola). This makes it the main source of indigenous tree seeds for the central highlands. According to wildlife surveys undertaken in 1982, there are about 180 specious of birds and 21 mammals in this forest reserve.

A number of rivers, including Awash, start from within the Chilimo. The vegetation throughout this area has been subject to human interference for over 2,000 years (longer than in any other East African country), and the rate of deforestation has been extremely high, with significant changes in forest cover observed even since the 1970s (Melaku, 2003). The forest is Montane-mixed broadleafconiferous, although conifers predominate. Historically, this entire upland area is thought to have been covered by Juniperus-Podocarpus forest, but most of the forest has been cleared for agriculture, and this encroachment continued. Selective cutting of trees for commercial use stopped about 1973, but illegal cutting by the local people for fuelwood sale continued. The forest is important to local people for grazing, fodder, commercial and subsistence fuelwood extraction, herbal medicine for humans and animals, farm implements, construction poles and timber and occasionally non timber forest products. A few shrub species dominate, such as Myrsine africana, with others like Maytenus arbutifolia and Rubus apetalus abundant indicators of forest disturbance. Small patches of plantation forests, initiated by the Forestry Department (FD) of the State in 1976, are present within the forested lands. Indigenous and exotic species are used; the main exotic species are Eucalyptus saligna, E. camaldulensis, Pinus patula and Cupressus lusitanica, with indigenous ones including Juniperus procera, Hagenia abyssinica and Podocarpus falcatus (Zelalem, 2005).

In response to failure of previous "fences and fines" approach, the FARM-Africa's Chilimo Participatory Forest Management phase I and II Projects were operational from 1996-2006 (Melaku, 2003). Also the 2003 Regional Legislation on Forest Management allows for devolution of management power and handover ownership status to local people or community based organizations (CBOs). PFM approach was introduced in 1996 as a strategy to arrest forest degradation and to meet the livelihood needs of the local community (Garma, 2000). Transferring the ownership of the forest was made in 2004 when the district cooperative promotion bureau legalized the by-laws of forest cooperatives, clarifying the responsibilities. The FCs and government signed a contractual agreement to manage the forest in jointly base and share both the responsibilities of and benefits from establishing and maintaining PFM (Garuma, 2000). Currently, there are 10 legally registered Forest Cooperatives (FCs) and two Forest User Groups (FUGs). From these ten forest cooperatives the eight were formed one forestry cooperative union-Chilimo-Gaji forest cooperative union. The following table (Table 2) shows detailed information of the FCs/FUGs.

Table 2. FCs Membership Statistics and Forest Holding Size in Chilimo-Gaji Forest.

\begin{tabular}{|c|c|c|c|c|c|c|c|c|c|}
\hline \multirow[t]{2}{*}{ S.N } & \multirow[t]{2}{*}{ Kebeles } & \multirow{2}{*}{$\begin{array}{l}\text { Name of forest } \\
\text { Cooperatives }\end{array}$} & \multirow{2}{*}{$\begin{array}{l}\text { Year of } \\
\text { Establishment }\end{array}$} & \multicolumn{3}{|c|}{ Forest Coverage(in ha) } & \multicolumn{2}{|c|}{$\begin{array}{l}\text { Number of } \\
\text { Members by Sex }\end{array}$} & \multirow{2}{*}{$\begin{array}{l}\text { Total } \\
\text { Number } \\
\text { members }\end{array}$} \\
\hline & & & & Natural & Plantation & Total & Male & Female & \\
\hline \multirow{3}{*}{1} & \multirow{3}{*}{ GareArera } & Chilimo & 1994 & 596 & 99 & 695 & 114 & 24 & 138 \\
\hline & & Mesalemiya & 1994 & 664 & 246 & 910 & 88 & 31 & 119 \\
\hline & & Jijiga & 1999 & 176 & 0 & 176 & 74 & 8 & 82 \\
\hline 2 & Galessa & Galessa & 1995 & 384 & 0 & 384 & 139 & 48 & 187 \\
\hline 3 & DanoEjersaGibe & DanoSangota & 1995 & 316 & 11 & 327 & 115 & 16 & 131 \\
\hline 4 & Tanko & Goban & 1999 & 188 & 0 & 188 & 69 & 14 & 83 \\
\hline
\end{tabular}




\begin{tabular}{|c|c|c|c|c|c|c|c|c|c|}
\hline \multirow[t]{2}{*}{ S.N } & \multirow[t]{2}{*}{ Kebeles } & \multirow{2}{*}{$\begin{array}{l}\text { Name of forest } \\
\text { Cooperatives }\end{array}$} & \multirow{2}{*}{$\begin{array}{l}\text { Year of } \\
\text { Establishment }\end{array}$} & \multicolumn{3}{|c|}{ Forest Coverage(in ha) } & \multicolumn{2}{|c|}{$\begin{array}{l}\text { Number of } \\
\text { Members by Sex }\end{array}$} & \multirow{2}{*}{$\begin{array}{l}\text { Total } \\
\text { Number } \\
\text { members }\end{array}$} \\
\hline & & & & Natural & Plantation & Total & Male & Female & \\
\hline \multirow{4}{*}{5} & \multirow{4}{*}{ YubdoLagaBatu } & Gaji & 1995 & 839 & 48 & 887 & 221 & 51 & 272 \\
\hline & & YubdoGerarsa & 2002 & 148 & 0 & 148 & 85 & 11 & 96 \\
\hline & & YubdoKashina & 2002 & 180 & 0 & 180 & 100 & 33 & 133 \\
\hline & & Togicha & 2002 & 241 & 0 & 241 & 67 & 18 & 85 \\
\hline 6 & GalessaKotaGeshar & Warabo & 1996 & 664 & 11 & 675 & 179 & 37 & 216 \\
\hline 7 & QabaBareda & Tiyo & 1996 & 133 & 0 & 133 & 47 & 11 & 58 \\
\hline
\end{tabular}

\subsection{Methodology}

\subsubsection{Sampling Design}

The study primarily focused on parts of Chilimo-Gaji forest which is currently under PFM program. There are forty eight rural kebeles in Dendi district that use the forest for different purpose. However, the PFM scheme is being implemented in seven kebeles. There are about 12 Forest Cooperatives (FCs) in the seven kebeles were formed at different time and were under various level of implementing PFM. The study employed multi-stage sampling procedure. First, the seven kebeles were purposively selected because PFM scheme was implemented in these seven kebeles. Second, one FC selected randomly from each of the seven kebele. Third, as it is clearly presented in table (3), 50\% of the women and $20 \%$ men members of the selected FCs randomly selected as sample respondents. So, the total sample size of the study was 277 households.

Table 3. Sample Size Distribution.

\begin{tabular}{|c|c|c|c|c|c|c|c|c|c|}
\hline \multirow[b]{2}{*}{ S.N } & \multirow[b]{2}{*}{ Kebeles } & \multirow{2}{*}{$\begin{array}{l}\text { Name of } \\
\text { Forest } \\
\text { Cooperatives }\end{array}$} & \multirow{2}{*}{$\begin{array}{l}\text { Year of } \\
\text { Establishment }\end{array}$} & \multicolumn{2}{|c|}{ Forest Coverage(in ha) } & \multicolumn{3}{|c|}{ Total Number of Members by Sex } & \multirow{2}{*}{$\begin{array}{l}\text { Total } \\
\text { Number } \\
\text { members }\end{array}$} \\
\hline & & & & Natural & Plantation & Total & Male(20\%selected) & Female(50\%selected) & \\
\hline 1 & $\begin{array}{l}\text { Gare } \\
\text { Arera }\end{array}$ & Chilimo & 1994 & 596 & 99 & 695 & $114(20 \%)=23$ & $24(50 \%)=12$ & 138 \\
\hline 2 & $\begin{array}{l}\text { Galessa } \\
\text { Dano }\end{array}$ & Galessa & 1995 & 384 & 0 & 384 & $139(20 \%)=28$ & $48(50 \%)=24$ & 187 \\
\hline 3 & $\begin{array}{l}\text { Ejersa } \\
\text { Gibe }\end{array}$ & Dano Sangota & 1995 & 316 & 11 & 327 & $115(20 \%)=23$ & $16(50 \%)=8$ & 131 \\
\hline 4 & $\begin{array}{l}\text { Tanko } \\
\text { Yubdo }\end{array}$ & Goban & 1999 & 188 & 0 & 188 & $69(20 \%)=14$ & $14(50 \%)=7$ & 83 \\
\hline 5 & $\begin{array}{l}\text { Laga } \\
\text { Batu } \\
\text { Galessa }\end{array}$ & Gaji & 1995 & 839 & 48 & 887 & $221(20 \%)=44$ & $51(50 \%)=25$ & 272 \\
\hline 6 & $\begin{array}{l}\text { Kota } \\
\text { Geshar }\end{array}$ & Warabo & 1996 & 664 & 11 & 675 & $179(20 \%)=36$ & $37(50 \%)=18$ & 216 \\
\hline 7 & $\begin{array}{l}\text { Qaba } \\
\text { Bareda } \\
\text { Total }\end{array}$ & Tiyo & 1996 & 133 & 0 & 133 & $\begin{array}{l}47(20 \%)=9 \\
177=64 \%\end{array}$ & $\begin{array}{l}11(50 \%)=6 \\
100=36 \%\end{array}$ & 58 \\
\hline
\end{tabular}

\subsubsection{Methods of Data Collection}

Both primary and secondary source of data were used for this study. The primary data were collected by semistructured questionnaire survey, focus group discussion and key informant interview.

Semi-Structured Questionnaires: Both qualitative and quantitative data from the participants were collected by using a semi-structured questionnaire survey. The questionnaires pre-tested to check the validity and adjustments conducted where necessary. The semi-structured questionnaire designed to collect data on nature of gender participation, level of gender participation in PFM activities such as forest protection, development and utilization and gender specific roles, responsibilities and rights, empowerment opportunities and determinants of gender participation. Since farmers in the study area speak Afan Oromo, the questionnaires that will initially prepared in English were translated to Afan Oromo. Fifteen enumerators, all diploma holders, recruited from the study area and twoday intensive induction training was given to them.
Key Informant Interview: Key-informants were drew from development agents (DAs) working in the sample kebeles), Experts from District Natural Resources Management, village leaders and Expert from the Oromia Forest and Wildlife Enterprise (OFWE).

Focus Group Discussion: Three focus groups consist of eight to ten persons with different backgrounds were established. Check-lists were prepared and these focused on the benefit sharing mechanisms, gender specific roles, responsibilities and rights, nature and level of gender participation in PFM activities and constraints of gender participation in PFM activities. Participants in this discussion were selected from ordinary members of FCs in the study area. In the respective groups of the study area, the group is divided in to two parts. That is the males group and the females group discussed separately and the division was purposely done to increase the confidence of female to speak more on the problem at hand.

Secondary Data: The major secondary sources includes books and periodicals, PFM related publications, seminar 
papers, conference proceedings and previous works such as dissertations as well as socio-economic, statistical publications as well as project reports, legislations and internal by-law of FCs.

\subsubsection{Methods of Data Analysis}

All the data collected from the field were coded and entered in to a SPSS data sheet. The entire dataset was then reviewed carefully. Reviewing was done for outliers, incorrect values and missing values. The collected data was analyzed by using the same software. Numerical data was analyzed through descriptive statistics like mean, frequency and percentage, chi-square and histograms; and results were presented in charts, figures and tables. The qualitative data obtained in the focus group discussions and key informant interviews were analyzed thematically.

\section{Results and Discussion}

\subsection{General Demographic and Socio-economic Attributes of the Respondents}

As it is presented in the table (4), out of the 277 sample household respondents, the majority $(64 \%)$ were men and the remaining $(36 \%)$ women. With regard to age structure of the sample respondent household heads, $15.8 \%$ are above 55 years old, $77.5 \%$ between the ages of 25 and 55 years, while only $6.7 \%$ are below 25 years old. The mean age of the sample respondents is 41 , with minimum and maximum ages of 22 and 78 years, respectively.

Larger family sizes would have more demand for forest products due to high consumption. The family size of the respondent households ranges from 3 to 11 members. The majority $(72.8 \%)$ have family sizes of five and above. The mean family size is about 6 indicating that the survey respondents have large household sizes. Regarding the sex of family members, survey results indicate a total of 1082 members, of which $52.5 \%$ are male, while the remaining $48.5 \%$ are female.

The educational status of a society, particularly literacy level, is among the key factors determining development and growth (Todaro and Smith, 2009). The Survey result in the table (4) indicates that the education level of the respondents is low: $49.2 \%$ are illiterate; $18.3 \%$ can read and write without attending any formal schooling; $21.7 \%$ got up to grade 4 ; while the remaining $10.9 \%$ attained above 4 th grade. The survey result also shows the education level of women sample respondents is relatively very lower than that of men respondents. $97 \%$ of women respondents were illiterate whereas $58 \%$ men were illiterate.

Table 4. General Demographic and Socio-economic attributes of the Respondents $(n=277)$.

\begin{tabular}{llll}
\hline Household Characteristics & Frequency & Percentages \\
\hline \multirow{2}{*}{ Gender } & Male & 177 & $64 \%$ \\
& Female & 100 & $36 \%$ \\
& $20-30$ & 33 & $12 \%$ \\
Age & $31-40$ & 89 & $32 \% \%$ \\
& $41-50$ & 133 & $48 \%$ \\
& $>50$ & 22 & $8 \%$ \\
\hline
\end{tabular}

\begin{tabular}{llll}
\hline Household Characteristics & Frequency & Percentages \\
\hline \multirow{3}{*}{ Family Size } & $2-5$ & 33 & $12 \%$ \\
& $6-10$ & 228 & $82 \%$ \\
& $>10$ & 22 & $6 \%$ \\
& Cannot read and write & 137 & $49.2 \%$ \\
Education & Can read and write & 51 & $18.3 \%$ \\
& $1-4$ & 60 & $21.7 \%$ \\
& $>4$ & 30 & $10.9 \%$ \\
& $0-0.5 \mathrm{ha}$ & 172 & $62 \%$ \\
landholding & $0.51-1 \mathrm{ha}$ & 75 & $27 \%$ \\
& $>1 \mathrm{ha}$ & 31 & $11 \%$ \\
\hline
\end{tabular}

Land is one of the assets that the rural livelihood highly depends upon, since agriculture is their main livelihood options. All the sample households had pieces of land though the size was very small for some of the respondents and they could considered functionally landless. The average land holding size is 0.575 ha with a standard deviation of 0.65 ha per household. Almost $88 \%$ respondents replied that they had a source of income other than forestry. While $12 \%$ respondents had only forestry as their income source, all of these respondents were women. Income sources other than forestry constitute sharecropping, day labour, small business, farming on own land and cattle raising. In the study area, it was found that agriculture was the main occupation for every household but household members undertook other activities in addition to agriculture. Out of the 272 respondents interviewed, about $72 \%$ had agriculture as their occupation. Small business, housewife (only for female participants) and day labour constituted the rest.

\subsection{PFM-Associated Incomes and Alternative Income Generating Activities (IGAs)}

Introduction of alternative Income Generating Activities (IGAs) with PFM is based on the foundation that the local communities are dependent on forest products (FAO, 1999) and that the forest degradation happens because the consumptive forest use is the only option for income generation to meet their livelihood needs. Communities must be compensated for their restricted access to the forest through alternative IGAs so that they refrain from environmentally destructive process because they are given alternative opportunity to earn incomes to meet their immediate livelihood needs. In the study area the most common income generating activities includes tree seedling production, beekeeping, and irrigation schemes, small loan to FC member households The focus group discussion results on other alternative IGAs such as beekeeping, irrigation schemes and tree seedling production shows that it was not gender-inclusive and didn't consider the women's ability to afford initial costs attached with the investment and preference consultation of women.

FGD at Chilimo Kebeles-Communities perception on Income Generating Activities Related with PFM

"There are Some income PFM-associated generation activities introduced in our kebeles. But we are suffering a lot from lack of consultation on decisions over which IGAs to promote, elite capture problems and inability to 
afford the initial investment costs and failure to meet immediate cash needs. We, very poor women and men households are not participating in IGAs we cannot afford the initial cost attached to the IGAs and for some IGA interventions prompted were are not familiar with. For example, beekeeping, households are required to buy beehives. In addition we would like to keep livestock because we are not used to beekeeping culture but we are not given that opportunity to choose. The only good thing is that the poorest and landless households allowed extracting dry woods and fallen trees for sale twice per a week without any charge. This enabled the poorest households to meet their immediate cash needs because there was no user fee that must be paid in advance of gaining forest access for commercial access. This made us, the very poor women household, care for the sustainability of the forest."

\subsection{Benefit Sharing Mechanisms}

The survey result reveals that the benefit sharing ratio between FCs and government was 70\%:30\% for income generated from first thinning and 90\%:10 \% for income generated from second harvest between forest cooperatives and government respectively. Then, in principle, each participatory forest management groups from their portion income they received as a cooperative organization should disburse $60 \%$ among member households, 20\% should be invested on community development works such as (purchasing office utensils, forest guard's pay in special cases, community livelihood improvement interventions, school building, road construction, village irrigation schemes, clinics) and $20 \%$ should be reserved for other purposes like giving loans to member families. Practically, in most cases the cash benefits were not distributed in compliance with the PFM rule 2004. This is not because of shortage of organizational financial capacity rather could result from elite capture and corruption problems. Also there are genders inequalities in benefit sharing mechanisms because entitlements are usually on household basis except in polygamy situations, so even when both spouses are members they get one share. In most cases cash benefits are distributed but usually the funds were put to uses from which women were unlikely to benefit, such as purchasing office and village utensils, chairs and tables (Table 5).

Table 5. Forest Cooperatives Funds principal uses.

\begin{tabular}{|c|c|c|c|c|c|c|c|c|c|}
\hline S.N & Use of funds* & $\begin{array}{l}\text { Chilimo } \\
(\mathrm{N}=44)\end{array}$ & $\begin{array}{l}\text { Galessa } \\
(52)\end{array}$ & $\begin{array}{l}\text { Dano Sangota } \\
(\mathrm{N}=31)\end{array}$ & $\begin{array}{l}\text { Goban } \\
(\mathrm{N}=\mathbf{2 1})\end{array}$ & $\begin{array}{l}\text { Gaji } \\
(\mathrm{N}=69)\end{array}$ & $\begin{array}{l}\text { Worabo } \\
(\mathrm{N}=54)\end{array}$ & $\begin{array}{l}\text { Tiyo } \\
(\mathrm{N}=15)\end{array}$ & Total \\
\hline 1 & Loan to member families & 14 & 12 & 6 & 4 & 10 & 6 & 5 & 57 \\
\hline 2 & Distributed to member & 44 & 52 & 31 & 21 & 69 & 54 & 15 & 286 \\
\hline 3 & $\begin{array}{l}\text { Purchase of office and community } \\
\text { utensils }\end{array}$ & 22 & 11 & 10 & 1 & - & - & - & 44 \\
\hline 4 & $\begin{array}{l}\text { Invested and on forest protection a } \\
\text { community development activities. }\end{array}$ & 25 & 10 & 8 & 8 & 8 & 8 & 7 & 74 \\
\hline 5 & Social Functions & 8 & 4 & 2 & - & 6 & 2 & - & 22 \\
\hline 6 & Not used so far & - & - & - & - & - & - & - & - \\
\hline
\end{tabular}

*Most of FCs uses the funds for more than one purpose.

Similarly, money given to men does not guarantee and prove equal sharing, or even any sharing, within the family (Table 5). The men typically spend a substantial part on none productive individual consumptive and entertainment purposes than household saving and consumption needs

\subsubsection{Communities' Preference on PFM-Associated Cash Benefits Distribution Mechanisms}

The survey result shows that an overwhelming majority $(84.5 \%)$ of women's tends to opt for equal and individual shares for each spouse of cash benefits distributed to FC member households where as the majority of men's opt for individual share for men spouses only. This could be because of money given to men household heads does not guarantee and prove equal sharing within households between women and men spouses and also men's failure to use effectively and efficiently for common goal.

Table 6. Communities' preference on PFM-linked cash benefits Distribution Mechanism.

\begin{tabular}{lll}
\hline Communities 's preference on cash benefits & \multicolumn{2}{l}{ Sex of the respondents } \\
\cline { 2 - 3 } disbursed & Men & Women \\
\hline Equal and individual share for each spouse & $22 \%$ & $84.5 \%$ \\
Individual share for men spouses only & $55 \%$ & $2.5 \%$ \\
Individual share for women spouses only & $20 \%$ & $14 \%$ \\
Don't know & $3 \%$ & - \\
\hline
\end{tabular}

\subsubsection{Communities Satisfaction with Shares in the PBSA}

The survey result shows all the 277 respondents had their shares of benefit from the first rotation, they were asked about their satisfaction with the share given in the Participatory Benefit Sharing Agreement (PBSA). The following table (Table 7) represents the reaction of the respondents regarding the PBSA.

Table 7. Satisfaction of Respondents with shares in the PBSA.

\begin{tabular}{|c|c|c|c|c|c|}
\hline & & Frequency & Percent & Valid Percent & Cumulative Percent \\
\hline \multirow{4}{*}{ Valid } & Satisfied & 210 & 75.8 & 75.8 & 75.8 \\
\hline & Dissatisfied & 55 & 19.9 & 19.9 & 95.7 \\
\hline & Neutral & 12 & 4.3 & 4.3 & 100.0 \\
\hline & Total & 277 & 100.0 & 100.0 & \\
\hline
\end{tabular}


As the survey result shows, $75.8 \%$ of the respondents were satisfied with their shares given in the PBSA. Some $19.9 \%$ respondents expressed their dissatisfaction with the shares given in the PBSA, while $4.3 \%$ remained neutral in expressing their opinion. This could suggest that the benefit sharing ratio between communities and the counterpart local government was reasonably satisfactory in terms of magnitude. It is not enough to share benefits, but the shared magnitude must also be sufficient enough to content the communities and to contribute to improved rural livelihoods. This finding confirms with other similar studies report (Blomley and Iddi, 2009) results sufficient economic benefits to participants is the pre-requisite to drive successful and sustainable PFM and because tangible benefits contribute to cohesiveness and sustainability of local forest management institutions. All the respondents who were dissatisfied with their shares considered the present share as inadequate and feel that it should be increased. They complain that all the forest development and protection activities under taken by them and government was passive in most of them. These groups claim that the communities deserve higher benefit sharing ratio than the established

\subsubsection{Comparative Analysis of Satisfaction of Men and Women FCs with Present Benefit Sharing Arrangement}

To study the difference in benefit sharing of PFM activities, responses of respondents about their satisfaction with the present benefit sharing arrangement of Men and women groups were compared. The chi square test of significance shows that the difference in responses between the groups was not significant.

Table 8. Chi-Square Test Results of satisfaction by Benefit Sharing Arrangement.

\begin{tabular}{llllll}
\hline \multirow{2}{*}{ Gender of respondents } & Frequency & & & \multirow{2}{*}{ Pearson $\chi^{2}$ value } & Significance level \\
\cline { 2 - 4 } & Satisfied & Neutral & Dissatisfied & 1.12 & 0.587 \\
\hline Men & 122 & 42 & 11 & 1 & \multirow{2}{*}{ Women } \\
\hline
\end{tabular}

(Source: Own Survey Results, 2014)

The table (8) shows that the present benefit sharing arrangement (FC groups 70\% and FD 30\%) seems to be acceptable to both the most benefited and the least benefited PFM groups.

\subsection{Rules for Membership and Women's Representation in Key Decision Making- Gender Sensitivity of FCs}

In the study area membership rule allows one man one woman per household. Moreover, where the woman automatically becomes a member by virtue of her husband being a member; it is he who is seen as the primary members. Only three PFM states allow membership to all village adults The unit of membership is the household, and in male-headed households the man's name alone is entered in the membership list So, it is somehow more inclusive than rules allowing membership to only one person per household which effectively exclude women (Agrawal, 2010). But, the most inclusive membership rule is which allows all adult household members to join the participatory forest management groups. The PFM groups broadly have a twotier organizational structure. General Assembly (GA) which drew members from the whole village and executive committee composed up of 22 persons and Executive Committee (EC). The general assembly meets twice a year and the executive committees' about once a month. The executive committee is accountable to general assembly. Both bodies, interactively, define the rules for forest use, the punishments for abuse and the methods of forest development and protection (e.g., guards, patrolling groups, etc.), benefit sharing mechanism and conflict resolution.

As the survey result (table) reveals that most women's are not even nominal members of Forest cooperatives. They in average constitute less than $20 \%$ of PFM general assembly. Galessa (20\% of GA) Dano Sangota ( $12 \%$ of GA), are the FCs consisting the highest and the lowest women members respectively. This variance is not created by difference in membership rules applied by both FCs. There is no membership eligibility criteria difference between the two FCs, but other factors such as availability of relatively more women headed household. Women's effective participation in PFM decision making would require that they not only become members of the group, but also attend and speak up at meetings, and can (at least some of the time) ensure that decisions are made in their favor. In other words, they would need to move from being absent or just nominal members to interactive (empowered) participants.

One aspect of PFM that came under repeated criticism was the inadequate representation of women and the poor on EC. The lack of participation by women greatly reduced their opportunity to share information and knowledge and voice their opinions. These FCs committees' are key decision makers in the PFM process. But women are underrepresented or not represented (table) at all in some FCs in executive committee. As a result, numerous activities could negatively impact on both women and their contribution to sustainable forest development. In addition, women's concerns weren't heard at EC meetings, due mainly to underrepresentation of women in ECs. Even the women included in the EC were not chosen by other women as their representatives. Male EC members chose the women in their absence and without consulting them. Such women in EC cannot be effective and influential. Some are nominal and others are even unaware that they are EC members. Excluding women while including men could worsen power relationships and further 
disempowering women. Indeed every new participative development intervention that ignores gender, be it forest user groups, water user groups, or credit groups, can potentially disempowered the women and/or the poorest marginalized segment of the society (Agrawal B, 2001)

Table 9. Composition of FCS Committee by Gender.

\begin{tabular}{|c|c|c|c|c|c|c|}
\hline \multirow{2}{*}{$\begin{array}{l}\text { Name of } \\
\text { FCs/FUGs }\end{array}$} & \multicolumn{4}{|c|}{ Total number of members (General Assembly) } & \multirow{2}{*}{$\begin{array}{l}\text { Total Number of members in key } \\
\text { decision making position (Total } \\
\text { Committee members) } \\
\text { Total members of Executive } \\
\text { committee }\end{array}$} & \multirow{2}{*}{$\begin{array}{l}\text { Number of Women in key } \\
\text { decision making position } \\
\text { (Committee members) }\end{array}$} \\
\hline & Male & Female & Total & $\begin{array}{l}\text { Percentage of member Women } \\
\text { in General Assembly }\end{array}$ & & \\
\hline Chilimo & 114 & 24 & 138 & $17 \%$ & 22 & $4.5 \%(1)$ \\
\hline Galessa & 139 & 48 & 187 & $25 \%$ & 22 & $9 \%(2)$ \\
\hline DanoSangota & 115 & 16 & 131 & $12 \%$ & 22 & $0 \%(0)$ \\
\hline Goban & 69 & 14 & 83 & $16 \%$ & 22 & $4.5 \%(1)$ \\
\hline Gaji & 221 & 51 & 272 & $18 \%$ & 22 & $4.5 \%(1)$ \\
\hline Warabo & 179 & 37 & 216 & $17 \%$ & 22 & $0 \%(0)$ \\
\hline Tiyo & 47 & 11 & 58 & $18 \%$ & 22 & $0 \%(0)$ \\
\hline
\end{tabular}

Equality in roles of men and women in FCs was primarily determined by their representation in the committee and their role in the decision making process. The inclusion of women in one-third of the total committee positions has become mandatory. This rule, however, has been breached by majority of FCs at the study sites in reality. In no FC women hold one-third of the positions in the executive committee. As observed in the table (9), women representation in FCs is very low. Moreover, the positions filled by women were mostly in the category of ordinary members that carried less responsibility. All important positions such as that of chairperson, secretary, treasurer, etc. were filled by men. In spite of the existing rules to have one-third of women in the committee in FCs women are underrepresented.

Women's participation in meetings, in general, was also reported to be negligible. And even where women were present; they did not speak until questions were specifically put to them. Without being members, women usually hear little of what transpires at GA or EC meetings, that is, they are not even passive participants. Women characteristically complain: Typically men don't tell their wives what happens in meetings. Even if there is a dispute about something, they don't tell us; nor do they volunteer information about other matter Even if the women who are GA or EC members, only a small percentage usually attend the meetings. If they do attend they rarely speak up, and if they speak their opinion carry little weight. Having a voice in the EC is important since this is the site for discussions and decisions on man central aspects of PFM group functioning. As matters stand, women are not party to most decisions. Even those who are members remain passive participants, far from the active or interactive even in my typology.

But the key informant interview data shows that the forest cooperative societies tried to address the issues of gender by considering both husband and wives as forest cooperative members and as in case of Polygamy wives women's were considered as independent members. Women were also represented in the leadership and key decision making position such as Forest cooperative member in both FC institutions although limited because of low literacy level, as explained by the key informants.

One key informant Woman (Saving and credit Committee chairperson in Mesalemiya FC) reported (January, 2014):

"One of the most significant achievements of the PFM and establishment of FC was the place women and disadvantaged social groups received in the whole set-up of the approach and forest cooperative. As result of the start of PFM in Mesalemiya the women have started to participate in the decision making processes concerning the forest and other means of livelihood, although their presence in the key decision making positions is very still low. Our forest cooperative society provided various capacities building training on Alternative Income Generation (IGAs) activities and credit service with great attention for women's and poor's. Now, they have become full masters of their home gardens and also actively participate in forest development, protection and benefit sharing. Levels of women's inputs in terms of idea, labor, and tools, etc and number of women's attending meetings were increasing from time to time."

\subsection{Most Common Forest Protection Methods Practiced}

The forest protection activities practiced in the study area include forest surveillance/patrolling, firebreaks clearance and maintenances and special protection (night surveillance/patrolling). The approach of participatory forest management originates primarily because of the failure of conventional command and control system to protect their plantations by forest guards and other staffs. Now the local communities patrol the forest. Both the women's and men's jointly patrol together. All patrols involve rotation among member households. The patrol size varies from 3 to 5 persons. Night patrolling is unusual and exclusively men's responsibility. Women's vigilance improves forest protection in important ways, especially because they are better able to dissuade other women from breaking the rules as well as catch female intruders. In fire fighting, likewise, women join in, and in several cases their alertness alone saves the forest. But none of this, however, adds up to interactive participation. 


\subsection{Household's Participation in Forest Development Activities}

The survey result shows that major forest development activities undertaken by FCs were includes hole digging, planting and hoeing, water diversion to nursery sites and watering seedlings, replanting and enrichment planting for forest restoration, seed collection and choice of species and land area to regenerated. Plantations are established by the PFM groups with the help of FD. FD provides saplings, fertilizer and other material support and PFM participants provide labor to establish plantation. The survey result shows, $70 \%$ of respondents replied that both FD and PFM groups jointly established plantations, while 23\% of respondents said that they establish their plantations on their own and $7 \%$ of respondents recounted that FD established their plantations. When respondents were asked to rate planting activities, a majority of them $(85 \%)$ agreed with the current practices while $10 \%$ of respondents did not approve it. About $5 \%$ of respondents remained neutral in expressing their opinion.

In the case of tending operation, more than half of the respondents (64\%) indicated that both FD and PFM groups jointly carried out tending operations. FD provides fertilizer and other materials required for tending and PFM group provides labour to complete the operation. $32 \%$ of respondents noted that FD did not support them in tending their plantation, thus they had to do it by themselves. While $4 \%$ of respondents indicated that FD alone tended their plantations. When respondents are asked to rate the current tending activities, a majority (88\%) agreed with the current practice against only $8 \%$ of respondents who did not agree.
Some $4 \%$ of respondents remained neutral in expressing their opinion regarding tending operation.

\subsection{Forest Use Rule Making}

The gender composition of ECs affects the nature of the forest use rules that the groups make. It is well recognized that a key element in the sustainability of FCs is the forest use rules and the process by which they are formulated and adapted to user needs. Regulated access to forest resources is very critical in maintaining or improving the forest condition. Protection and management practices of the FCs in the study area were regulations on grazing and extraction of forest products, selective retention of tree species and silvicultural operations. The willingness and committed compliance of communities' to regulated access to grazing and extraction of forest products were the practical indicators and are prerequisite for the success of the forest conservation effort. The reduced trespassers report from time to time could be one practical evident of the communities committed compliance with FCs by-laws and regulations.

As the data presented in the table (10) shows, the overwhelming majority, $60.65 \%$ (168) of the sample respondents preferred regulated access for both FC member households and non member households to the forest land. It could suggest that the changes in attitude toward the forest and raised awareness of the communities on the indispensability of the sustainability of the forest for their livelihood and ecological balance. Previously the communities perceived the forest as the 'adversaries 'property and illegally overexploited severely deforested when the different regimes of Ethiopia tried to protect through employed guards (Melaku Bekele, 2003)

Table 10. Communities Access preference.

\begin{tabular}{|c|c|c|c|}
\hline & Preference of Access Mode & Frequency & Percentage \\
\hline \multirow{4}{*}{$\begin{array}{l}\text { What mode of access mode do you } \\
\text { prefer for members and non member } \\
\text { households? }\end{array}$} & Free Access for FC Member Households Only & 22 & 11.6 \\
\hline & Free Access for Both FC Members and Non Members & 12 & 4.3 \\
\hline & Controlled Access for Both FC Members and Non Members & 1233 & 84.1 \\
\hline & Total & 277 & 100 \\
\hline
\end{tabular}

The communities allowed extracting dead and fallen trees and branches for commercial and domestic purpose. To extract forest resources such as building poles/posts and farm implements, they should apply to their respective FCs executive committee. Only FC member households are allowed to extract these products. The communities allowed to extract forest products especially, fuelwood for sell on the bases of their well-being category. Accordingly, the poorest, widowed women and landless FCs member households were permitted to extract head-load fuelwood for sell two times per a week. The respective FCs records and qualitative data from key informants and FGDs indicated that area and time based banning of grazing commonly practiced. Some forest patches (natural forests used for source of seed) were totally banned for grazing. In the plantation forests the forest lands were banned of grazing in 'Kermit' seasons for enrichment planting. Banning or though desirable in disturbed or degraded forest areas, may have adverse implications for livestock-owning families, particularly the small landholder farmers, as they had very small land to graze their cattle and grow Crop.

\subsection{Gender Participation in PFM-Associated Meetings and Influencing Decisions}

PFM related meetings that the FCs engaged were general assembly meeting, urgent meetings and meetings for expert input (for consultation in case of problems) Women's participation in PFM-associated meetings was very low. As a result, numerous activities could negatively impact on both women and their contribution to sustainable forest development. In addition, women's concerns weren't heard at EC meetings, due to mainly to underrepresentation of women in ECs. Even when women were physically present at meetings their views weren't heard. Women are interested in ensuring increased and sustained availability of NTFPs, and 
men are generally interested in maximizing monetary returns. But during meetings, only men's opinions appeared to be taken into account. The limited involvement of women also meant that the choice of species for planting in PFM areas was often decided by men, who chose cash profits over fuel and fodder yields. This reduced women's involvement and interest in the sustainable management of forest resources. The survey result in the table (11) reveals that only about $10 \%$ of the women's mostly speak up and try to challenge decision making process.

Table 11. Frequency of women's Speak up and influencing indecisions.

\begin{tabular}{lll}
\hline $\begin{array}{l}\text { Q. How often do you speak up in } \\
\text { PFM-associated meetings? }\end{array}$ & Men & Women \\
\hline Mostly & $130(73.4 \%)$ & $10(10 \%)$ \\
Occasionally & $42(23.72 \%)$ & $32(32 \%)$ \\
Not tall & $5(2.8 \%)$ & $58(58 \%)$ \\
\hline
\end{tabular}

This low proportion of women's speaking in meetings could be attributed to the fact that, as Behera and Engel (2005) argued; these women's lacked capacity building training and empowerment interventions and gender sensitive institutional supports and hence fails to present themselves and their point of view effectively in meetings. As result women groups could not tend to speak in PFM meetings while men's tended to be more vocal. This implies although they attend PFM meetings they are still de facto kept out of decision making process, which is likely to have serious repercussion as the more dominant groups pass decision biased to their interest which are likely to be different from those of the passive recipient

\subsection{Nature and Extent of Participation by Gender}

As described in the theoretical framework section, this study used Agarwal's framework of typology of participation (Agarwal, 2001) to identify the level of men's and women's participation in PFM-related activities. Based on this framework, the study found significant gender difference in even in nominal, passive and consultative participation level (see Figure 1). Most women are not even nominal members: they constitute less than $20 \%$ of most PFM general assembly. In the study area, the PFM membership criteria in the GA and other key decision making position like executive committee and working committee are almost very low. GA membership allowed to only one person per household. So, this automatically excludes women's except widowed and polygamy.

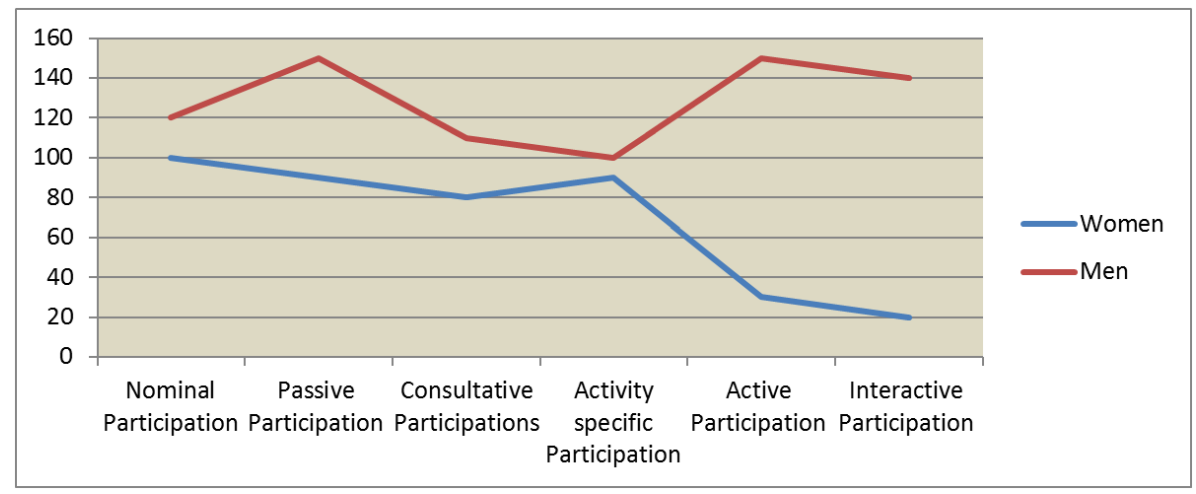

Figure 1. Topology of participation by gender.

Women's representation in EC is typically low. In PFM groups studied, $70 \%$ had no women EC members. Sometimes male EC members even chose the women in their absence and without consulting them. Such women are seldom active or effective. In the study are women's presence in most ECs is nominal. Often those who join are poorly informed of their FC's/FUG's activities, some are even unaware that they are EC members.

Equally, male PFM group members and forest officials seldom consult women when framing forest use rules or preparing micro-plans for forest development. Some women hear about the plans though their husbands, others not at all. As the main fuel and fodder collectors, women are often found to know more than men about the attributes of trees with such use values and to be better informed about the local environment where they gather and collect, while men are found more knowledgeable about the species they use or those found in distant areas. Failing to consult women means that their existing knowledge of diverse species does not enrich forest regeneration programs. At the same time, women have less chance of acquiring new knowledge, such as about new silviculture practices, since they are rarely part of the PFM group teams that receive such training.

Thus, despite their central stake as users and their familiarity with forests, women have little say in PFM decisions. An analysis of five PFM villages in Chilimo revealed that all major decisions on forest protection, use, distribution of wood and grass, and future planning, were taken by men. The only joint decision with women was about tree nurseries. Despite their absence from decision making, women get drawn into specific activities, especially protection and physical forest development activities. In formal terms, protection of the boundled area is usually done by forming a patrol group from among the member households. A male guard or an all-male patrol is typical: these two methods respectively characterized $60 \%$ of the 7 sites I visited. Female guards were rare, and only a small percentage of patrols had either sexes or women alone. 
However, somehow similarity is observed in activity-specific and interactive participation. For activity-specific participation, almost $90 \%$ of the surveyed female respondents said they regularly undertook specific activities or roles related to community forestry and fulfilled those obligations independently and on time, demonstrating their keen interest and active engagement in community forestry at different levels and in all sorts of activities Women's watchfulness improves protection in important ways, especially because they are better able to dissuade other women from breaking the rules as well as catch female intruders. In fire fighting, likewise, women join in, and in several cases their alertness alone saved the forest. None of this is however, adds up to interactive participation.

In terms of interactive participation, which is regarded as the highest level of participation based on the framework, the data shows clear domination by men as $90 \%$ of them are found to be actively engaged. The survey revealed that empowering activities like taking their own initiatives, being involved in conflict resolution tasks and actively engaging in organizing and coordinating training with external organizations are often undertaken by male members of the community.

\subsection{Constraint of Women's Participation}

Generally, institutional, economic, socio-cultural, political psychological ethos of a community can constrain or enhance gender inclusiveness in a given development efforts. But, here the issue what are the specific constraints hindering women's participation in PFM process before and after joining the FCs. As the survey result in the table (12) shows that the majority $(40 \%)$ responded that gender division of labour in the study is constrain women's participation in PFM practices and system. The fact that women bear the main responsibility for childcare and housework, in addition to their share of agricultural work, livestock rearing and other community/social responsibility makes for high work burdens. Men are reluctant to share not just domestic tasks and childcare, but even livestock care. This seriously restricts women's ability to attend lengthy meetings held at inconvenient times. While $28 \%$ respondents replied societal perception towards women's capability to shoulder different PFM associated responsibilities. Negative perception concerning women' abilities also impinge on men's reluctance to involve women. Men often perceive women's involvement in PFM groups as serving no useful purpose and tend to downplay their potential contribution.

Table 12. Factors Constraining Women's Participation in PFM.

\begin{tabular}{ll}
\hline $\begin{array}{l}\text { Q. What factors are constraining you from } \\
\text { involving in PFM system and practice? }\end{array}$ & Frequency \\
\hline Unfavorable membership rules /rules of entry & $24 \%$ \\
Educational level and awareness issues & $16 \%$ \\
Social perceptions concerning women's ability & $28 \%$ \\
Personal attributes and self-esteem/confidence & $16 \%$ \\
Gender division of labour & $40 \%$ \\
Poverty and poor household economic status & $8 \%$ \\
\hline
\end{tabular}

Almost 24\% respondents replied that rules of entry constrain their involvement in PFM system. In the study area rules determines membership in the GA. As noted earlier, rules allowing membership to only one person per household automatically exclude women. Whereas $16 \%$ of the respondent replied that their educational level and personal attributes constrains them from actively involving in PFM processes. $8 \%$ of the responded replied that poverty and poor household economic status constrains them PFM from actively involving in PFM process.

\section{Conclusion}

To sum it up it can be concluded that PFM system in the study area is still very much gender exclusionary. Though there is attempt to introduce alternative Income Generating Activities (IGAs) such as beekeeping, credit service, irrigation schemes, tree seedling production and etc with PFM, there is serious gap in considering and targeting the women's and the poorest household Communities specially women and landless must be compensated for their restricted access to the forest through alternative IGAs so that they refrain from environmentally destructive process because they are given alternative opportunity to earn incomes to meet their immediate livelihood needs. Planning and decision-making activities are almost fully excluding women's whereas specific implementation activities such as benefit sharing, forest protection and development activities are to some extent inclusive to women's. PFM participants involve themselves in activities like planting, tending, thinning and protection of plantations and also in sharing benefits obtained from the felling of such plantations. However, PFM participants have little or no involvement in the planning and decision making of PFM activities. Forest department and the men's dominating the decision making of activities like participant selection for training, species selection for PFM activities, selection of group leaders and other portfolios. Moreover, decisions like participant selection for PFM activities, thinning regime, final harvesting of plantations and preparation of participatory forest management plan are made only by FD.

\section{Recommendations}

Based on the general findings of the study and focus group discussion the following recommendations proposed.

a) More extensive capacity building and empowerment program should be conducted by district forest office to make women an active co-manager and user

b) Women's nominal membership in GA as well as representation is very low in key decision making positions. So the FD should implement the most inclusive membership criteria like allowing all adult members of household members and for women's representation case in key decision making positions like EC and working committee closely following the implementation of already existing rule that is one third 
of EC members should be women's.

c) Special provision should be made in the operational plan about women's participation in PFM and women's representation in the committee.

d) There are some obstacles such as poor Educational status, poor economic status, gender based labour division, occupation and should be minimized through different awareness program

e) The introduced alternative income generating activities (IGAs) such as beekeeping, credit service, irrigation schemes, tree seedling production and etc with PFM had serious gap in considering and targeting the women's and the poorest household communities. Women and landless must be compensated for their restricted access to the forest through alternative IGAs so that they can refrain from environmentally destructive process because they are given alternative opportunity to earn incomes to meet their immediate livelihood needs

\section{References}

[1] Agarwal, B (2001). Participatory Exclusions, Community Forestry, and Gender: An Analysis for South Asia and a Conceptual Framework. World Development, 29(10).

[2] Agarwal, B., (2010). Gender and Green Governance: The Political Economy of Women's Presence within and Beyond Community Forestry. Oxford University Press, UK.

[3] Arnstein, R(1969) A Ladder of Citizen Participation http://lithgow-schmidt.dk/sherry-arnstein/ladder-of-citizenparticipation.html, originally published in JAIP, Vol. 35, No. 4, July 1969.

[4] Bedru, B. (2007). Economic valuation and management of common-pool resources: the case of enclosures in the highlands of Tigray, Northern Ethiopia. PhD dissertation. Leuven, Belgium.

[5] FAO, (2012). Forests and Gender in a Changing Environment. Asia- Pacific Forests and Forestry to 2020: Forest Policy Brief 08 .

[6] FAO, (2007). Gender mainstreaming in forestry in Africa. Regional report. Report of a project carried out under the FAO Netherlands partnership program. Food and Agriculture Organization of the United Nations, Rome.

[7] FARM Africa (2005). Rapid forest assessment of Bonga forest. Addis Ababa: Ethiopia.

[8] Garuma Gudeta (2000). Study of Forest-related contributions to household economy, Chilimo Participatory forest Management Project: Dendi District, west Shewa Zone, and Oromia regional State, Ethiopia.
[9] Habtemariam Kassa, B., Campbell, M., Sandewall, Mamo Kebede, Tsegaye Yimiru , Gesese Dessie, Abebe Saifu, Mesfin Tadesse, Ephrem Garedew and K., Sandewall. (2009). Building future scenarios and uncovering persisting challenges of participatory forest management in Chilimo Forest, Central Ethiopia. Journal of Environmental Management 90: 1005-1012.

[10] Melaku Bekele. (2003). Forest Property Right, the role of the state and institutional exigency: The. Ethiopian experience. Doctoral Thesis, Swedish University of Science, Uppsala, Sweden.

[11] Mulugeta Lemenih and Melaku Bekele (2008) Participatory Forest Management Bes Practices, Lesson Learnt and Challenges Encountered: The Ethiopian and Tanzanian Experiences. FARM-Africa/SOS-Sahel. Addis Ababa.

[12] Nemarundwe, N. (2003) Negotiating Resource Access: Institutional Arrangements for Woodlands and Water Use in Southern Zimbabwe. Doctoral Thesis, Swedish University o Agricultural Sciences, Uppsala, Sweden.

[13] Ostrom, E. (1990). Governing the Commons: The Evolution of Institutions for Collective Action." Cambridge University Press, Cambridge, Massachusetts.

[14] Ostrom, E., and H. Nagendra. (2006). "Insights on Linking Forests, Trees, and People from the Air, on the Ground, and in the Lab." Proceedings of the National Academy of Sciences USA 103: 19224-1933.

[15] Saldanha, M. (2007). Colonial forest regulation and collective resistance: nineteen-century Thana District, India. In S. J. Carswell (eds), Environment, Development and Rural livelihoods (p. 98). London: Earthscan.

[16] Shackleton, C. M., S. E. Shackleton, E. Buiten, and N. Bird. (2007). "The importance of dry woodlands and forests in rural livelihoods and poverty alleviation in South Africa." Forest Policy and Economics 9: 558-577.

[17] USAID (2006). Issues in Poverty Reduction and Natural Resource Management. United States Agency for International Development, Washington, DC.

[18] USAID. 2001. Gender and community conservation. USAID office of women in development, Gender research project No. 3.

[19] Winberg, E. (2010). Participatory Forest Management in Ethiopia, Practices and Experiences. FAO Sub Regional Office for Eastern Africa. Addis Ababa.

[20] World Bank (2000). World Development Report: Attacking Poverty. World Bank, Washington DC.

[21] Zelalem Temesgen and Mulugeta Limenih (2012). Guideline to Scaling-up Participatory forest management. Addis Ababa: Ministry of agriculture.

[22] Zelalem Temesgen. (2005)An introduction to Chilimo Participatory Forest Management Project: Addis Ababa, Ethiopia. 